\title{
Derivation mathematical equations to estimate water surplus and groundwater recharge in Iraq
}

\author{
Hussein Ilaibi Zamil Al-Sudani ${ }^{1}$
}

Received: 12 June 2019 / Accepted: 13 March 2020 / Published online: 23 March 2020

(c) The Author(s) 2020

\begin{abstract}
Climate and hydrological conditions in any hydrological basin are multi-combined reflection of natural factors of morphology and soil nature, as well as the changing in climate factors that affect directly the hydrological cycle. The water balance equation for any natural area or water body indicates the relative values of inflow, outflow, and change in water storage for the area or water body. Estimation of water surplus and natural groundwater recharge in Iraq depending on water balance equation and meteorological data was the aim of this research. Corrected potential evapotranspiration were compared with annual and monthly rainfall in (32) meteorological stations to obtain actual evapotranspiration using water balance equation. Water surplus was divided into runoff and natural groundwater recharge where runoff coefficient method was used to estimate runoff. The obtained mathematical relationship between rainfall with both water surplus and actual evapotranspiration can be used to estimate these two parameters directly from rainfall. The results indicate that water surplus increased toward northeast direction of Iraq, while the minimum values of runoff and groundwater recharge located in western desert of Iraq. The climate conditions of desert were the major influence on reducing rainfall and rising temperature resulting decreasing water surplus, runoff, and groundwater recharge.
\end{abstract}

Keywords Derivation mathematical equations $\cdot$ Water surplus estimation $\cdot$ Runoff and groundwater recharge $\cdot$ Iraq

\section{Introduction}

Climate and hydrological conditions in any hydrological basin are multi-combined reflection of natural factors of morphology and soil nature, as well as the changing in climate factors that affect directly on hydrological cycle (AlSudani 2018a).

The hydrology section is divided into two main components, surface water and groundwater, where hydrologic cycle which occurs continuously in nature is the water transfer cycle (Subedi and Chávez 2015).

The study of the water balance is the application in hydrology of the principle of conservation of mass, often referred to as the continuity equation. This states that, for any arbitrary volume and during any period of time, the difference between total input and output will be balanced by

Hussein Ilaibi Zamil Al-Sudani

dr.hussein_alsudani@yahoo.com;

150098@uotechnology.edu.iq

1 Petroleum Technology Department, University of Technology, Baghdad, Iraq the change of water storage (UNESCO 1971). Knowledge of the water balance assists the prediction of the consequences of artificial changes in the regime of streams, lakes, and groundwater basin (Sokolov and Chapman 1974). Classical method of water balance calculations considers precipitation on the input side and runoff, evaporation, and infiltration on the output one. It aims at the best estimate possible of the water balance components with the simplest formulation and the minimum set of input data (Al-Sudani 2019a). The water balance equation can be expressed as follows (Domemico and Schwartz 1998):

Input - output $=$ change in storage.

Rainfall is the only input element in the water balance, where set of outputs as evaporation, transpiration, and consumption. Evaporation reflects the loss of water from water surfaces or soil, while transpiration and consumption are a process of water evaporation from plants, these two processes are called potential evapotranspiration (PE), which reflected the water losses with abundant quantity of water that exist in the basin area, and it can be calculated by specific equations, while actual evapotranspiration (AE) can be

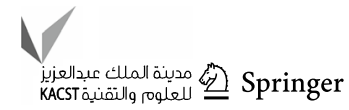


determined when quantity of water is limited (Al-Sudani 2018b). The second element of the water balance is soil moisture content, which depends on soil type, texture, and depth. This element affects on surface runoff and groundwater recharge, which represent the last elements of the water balance (Al-Sudani 2018b). One of the most important outcomes in water balance equation for any natural area or water body is evapotranspiration, and it is also a crucial component of hydrologic cycle (Abdullah et al. 2014). It can be defined as combination of two separate processes through which, water is lost from the soil surface via evaporation process and from the crop by transpiration (Allen et al. 1998). Thornthwaite method is one of the significant methods used to estimate the potential evapotranspiration (PE) that is based on the monthly average temperature. This method can be appropriately used in arid and semiarid regions (Henderson 2012). Potential evapotranspiration can be calculated by applying following formula (Al-Sudani 2018b):

$\mathrm{PE}=16\left[\frac{10 \mathrm{tn}}{J}\right]$,

$J=\sum_{1}^{12} j$

$j=\left[\frac{\mathrm{tn}}{5}\right]$,

$a=0.016 J+0.5$, where $\mathrm{PE}$ is potential evapotranspiration, $J$ heat index, $j$ coefficient monthly temperature $\left({ }^{\circ} \mathrm{C}\right), a$ constant, and tn average monthly temperature $\left({ }^{\circ} \mathrm{C}\right)$.

Prediction of monthly evapotranspiration can be obtained depending on observed monthly average temperatures at a meteorological station in each year, despite the fact that this formula is shown by many researches to underestimate (PE), and it has been accepted widely around the globe (Vangelis et al. 2013).

Using meteorological data to calculate water balance in Iraq depending on Thornthwaite method is the aim of this research. The water balance will predict water surplus and water deficit. The calculation of water balance will facilitate hydrological studies of lakes, river basins, and groundwater basins outcomes as well as reducing cost and time.

Iraq is sited between latitude $\left(29.00^{\circ}-37.22^{\circ} \mathrm{N}\right)$ and longitude $\left(38.45^{\circ}-48.30^{\circ} \mathrm{E}\right)$, while climate of Iraq is generally as continental and subtropical semiarid type, whereas the mountainous regions are classified a Mediterranean climate. It is characterized by a very hot summer and a short cold winter and also by the breadth of the daily and annual temperature because of the lack of large water bodies that reduce the coldness of winter and summer heat (Al-Sudani 2019b).

Several pervious studies and researches were used meteorological data within Iraqi locations either for estimating water balance or other different purposes. Some of these researches were applied locally, while others researches were applied in large basins of Iraq as mentioned below:

- Hyrogeological System of Debagah Basin In North of Iraq (Al-Sudani 2003).
Table 1 Geographical position of meteorological stations in Iraq (Al-Sudani 2019a)

\begin{tabular}{|c|c|c|c|c|c|c|c|}
\hline \multicolumn{2}{|c|}{$\begin{array}{l}\text { Location of sta- } \\
\text { tions }\end{array}$} & \multirow[t]{2}{*}{ Name of station } & \multirow[t]{2}{*}{ Station no. } & \multicolumn{2}{|c|}{$\begin{array}{l}\text { Location of sta- } \\
\text { tions }\end{array}$} & \multirow[t]{2}{*}{ Name of station } & \multirow[t]{2}{*}{ Station no. } \\
\hline Long. & Lat. & & & Long. & Lat. & & \\
\hline 444300 & 323300 & Ainaltamer & 1 & 433600 & 354500 & Makhmoor & 17 \\
\hline 471000 & 315100 & Amarah & 2 & 430900 & 361900 & Mosul & 18 \\
\hline 415700 & 342800 & Anah & 3 & 441900 & 315900 & Najaf & 19 \\
\hline 450400 & 325500 & Azizyah & 4 & 421500 & 320200 & Nukhaib & 20 \\
\hline 414400 & 360200 & Baaj & 5 & 461400 & 310500 & Nasiriyah & 21 \\
\hline 455700 & 330600 & Badra & 6 & 410100 & 342300 & Qaim & 22 \\
\hline 441400 & 331400 & Baghdad & 7 & 420600 & 364800 & Rabiah & 23 \\
\hline 432900 & 345600 & Baiji & 8 & 430900 & 332700 & Ramadi & 24 \\
\hline 474700 & 303400 & Basrah & 9 & 401700 & 330200 & Rutba & 25 \\
\hline 445900 & 315900 & Diwaniyah & 10 & 435300 & 341100 & Samaraa & 26 \\
\hline 460300 & 321000 & Hai & 11 & 451600 & 311800 & Samawah & 27 \\
\hline 442700 & 322700 & Hilla & 12 & 415000 & 361900 & Sinjar & 28 \\
\hline 440100 & 323700 & Karbalaa & 13 & 422900 & 362200 & Tel-Afer & 29 \\
\hline 443200 & 335000 & Khalis & 14 & 434200 & 343400 & Tikrit & 30 \\
\hline 452600 & 341800 & Khanaqin & 15 & 443900 & 345300 & Tuz & 31 \\
\hline 442400 & 352800 & Kirkuk & 16 & 360900 & 440000 & Erbeel & 32 \\
\hline
\end{tabular}

يولينة الملك عبدالعزيز

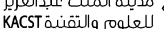




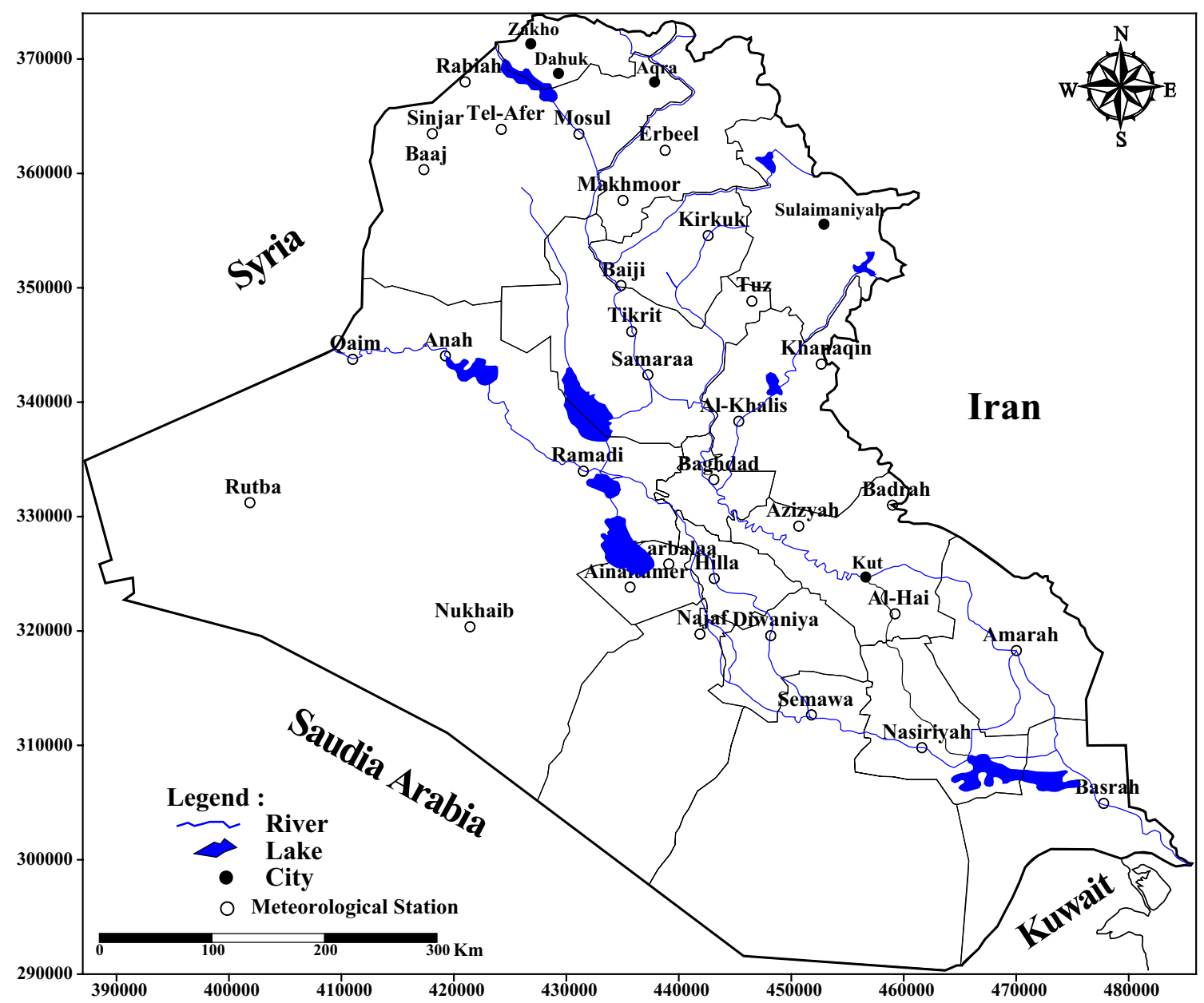

Fig. 1 Distribution map of meteorological stations in Iraq

- Water Balance of North Erbeel Basin (Al-Shamma et al. 2007)

- Calculating of Groundwater Recharge using Meteorological Water Balance and Water level Fluctuation in Khan Al-Baghdadi Area (Subedi and Chávez 2015).

- Climatic Water Balance and Hydrogeological characteristics of Lailan Basin, Southeast Kirkuk, North of Iraq (Al-Kubaisi and Rasheed 2018).

- Study of Morphometric properties and Water Balance using Thornthwaite method in Khanaqin Basin, East of Iraq (Al-Sudani 2018b).

- Investigation of Water Balance Methods of Haqlan Basin in the Western Region of Iraq (Saud et al. 2016).

- Groundwater system of Dibdibba sandstone aquifer in south of Iraq (Al-Sudani 2019c).

- Assessment of groundwater resources in Iraq and management of their use (Jawad and Ridha 2008).

- Temperature-Potential Evapotranspiration Relationship in Iraq Using Thornthwaite Method (Al-Sudani 2019a).
- Hydrogeological Investigations for sector 9.5th Stage, Badra-Jassan Region, East of Iraq (Al-Sudani et al. 2000).

- Derivation Mathematical Equations for Future Calculation of Potential Evapotranspiration in Iraq, a Review of Application of Thornthwaite Evapotranspiration (AlSudani 2019b).

- Estimation of Water Balance in Iraq using Meteorological Data (Al-Sudani 2019d).

- Rainfall Returns Periods in Iraq (Al-Sudani 2019e).

\section{Material}

The materials used in this research were:

1. Annual and monthly temperature and rainfall records for (32) meteorological stations with their geographic coordinates from date of station operation until 2016 (Iraqi Meteorological Organization and Seismology 2015). 
Table 2 Mean rainfall, (PEc), (AE), and (WS) in meteorological station in Iraq

\begin{tabular}{|c|c|c|c|c|c|c|}
\hline St. no. & $\begin{array}{l}\text { Ave. sum of } \\
\text { rainfall }(\mathrm{mm})\end{array}$ & $\begin{array}{l}\text { Ave. sum of potential } \\
\text { evapotranspiration }(\mathrm{mm})\end{array}$ & $\begin{array}{l}\text { Ave. sum of actual evapo- } \\
\text { transpiration }(\mathrm{mm})\end{array}$ & $\begin{array}{l}\text { Ave. sum of water } \\
\text { surplus (mm) }\end{array}$ & water surplus \% & $\begin{array}{l}\text { Duration } \\
\text { (years) }\end{array}$ \\
\hline 1 & 92.469 & 1579.066 & 72.88234 & 19.58666 & 21.18 & 20 \\
\hline 2 & 178.687 & 2318.14 & 103.6623 & 75.02467 & 42 & 35 \\
\hline 3 & 142.529 & 1388.118 & 97.11806 & 45.41094 & 31.86 & 38 \\
\hline 4 & 117.814 & 2014.677 & 82.7288 & 35.0852 & 29.78 & 15 \\
\hline 5 & 229.04 & 1361.543 & 112.2714 & 116.7686 & 50.98 & 17 \\
\hline 6 & 204.843 & 2330.101 & 108.4218 & 96.42122 & 47.07 & 15 \\
\hline 7 & 136.702 & 1674.369 & 92.2237 & 44.4783 & 32.5 & 66 \\
\hline 8 & 199.6981 & 1697.278 & 116.6699 & 83.02824 & 41.57 & 30 \\
\hline 9 & 144.805 & 2132.123 & 102.3255 & 42.47953 & 29.33 & 67 \\
\hline 10 & 112.441 & 2033.104 & 84.34017 & 28.10083 & 25 & 38 \\
\hline 11 & 139.17 & 2139.199 & 96.59776 & 42.57224 & 30.6 & 68 \\
\hline 12 & 108.981 & 1773.72 & 80.0853 & 28.8957 & 26.51 & 25 \\
\hline 13 & 103.4592 & 2087.377 & 76.60349 & 26.85571 & 25.95 & 38 \\
\hline 14 & 162.6836 & 1511.515 & 106.5557 & 56.12789 & 34.5 & 17 \\
\hline 15 & 308.659 & 1751.833 & 140.8596 & 167.7994 & 54.36 & 60 \\
\hline 16 & 376 & 1662.425 & 152.2042 & 223.8048 & 59.52 & 68 \\
\hline 17 & 306.914 & 1792.035 & 143.459 & 163.455 & 53.2 & 19 \\
\hline 18 & 372.995 & 1327.295 & 148.0522 & 224.9428 & 60.3 & 70 \\
\hline 19 & 94.05 & 2185.641 & 73.0197 & 21.0303 & 22.36 & 40 \\
\hline 20 & 72.1554 & 1579.066 & 63.18704 & 8.96836 & 12.42 & 20 \\
\hline 21 & 119.4807 & 2257.156 & 90.5997 & 28.881 & 24.17 & 73 \\
\hline 22 & 140.624 & 1383.538 & 98.24673 & 42.37727 & 30.13 & 20 \\
\hline 23 & 367.12 & 1122.652 & 160.1051 & 207.0149 & 56.39 & 31 \\
\hline 24 & 110.512 & 1515.101 & 86.3939 & 24.1181 & 21.82 & 25 \\
\hline 25 & 116.65 & 1182.171 & 93.06902 & 23.58918 & 20.22 & 35 \\
\hline 26 & 151.5433 & 1845.079 & 101.488 & 50.05526 & 33.03 & 26 \\
\hline 27 & 104.682 & 2242.733 & 78.98249 & 25.69951 & 24.55 & 38 \\
\hline 28 & 389.308 & 1399.499 & 153.8117 & 235.4963 & 60.5 & 42 \\
\hline 29 & 322.8445 & 1464.71 & 139.7751 & 183.0694 & 56.7 & 25 \\
\hline 30 & 181.878 & 1910.049 & 104.8913 & 76.9867 & 42.32 & 24 \\
\hline 31 & 254.026 & 1768.054 & 136.522 & 117.504 & 46.25 & 17 \\
\hline 32 & 449 & 1488.116 & 305.302 & 143.697 & 32 & 40 \\
\hline
\end{tabular}

2. Thornthwaite formula (Thornthwaite 1948).

3. Water balance equations (Al-Sudani 2018b, 2019a; Domemico and Schwartz 1998).

4. Runoff coefficient method (Garg 2013).

5. Excel, Grapher, and Surfer programs demonstrating tables of results and contour maps and figures.

The method adapted in this article depends on empirical methods belong to Thornthwaite formula. The basic assumption considered that temperature is an excellent parameter of the evaporative influence of the atmosphere. This method became very common due to limited data requirements (Mohammed and Scholz 2017).
Annual and monthly air temperatures of 32 meteorological stations distributed in Iraq used to calculate potential evapotranspiration (PE) using Thornthwaite method. These stations were divided according to Iraqi geographic latitude from (30-31) in the south to (36-37) in the north of Iraq, Table 1 Fig. 1. Calculated potential evapotranspiration (PE) was compared with temperature in all stations located in the same sector. Statistical approach was used to identify the types of equations for each group of stations using Grapher program. Finally, Surfer program was used to demonstrate contour map of heat and corrected potential evapotranspiration $(\mathrm{PEc})$ in Iraq. 


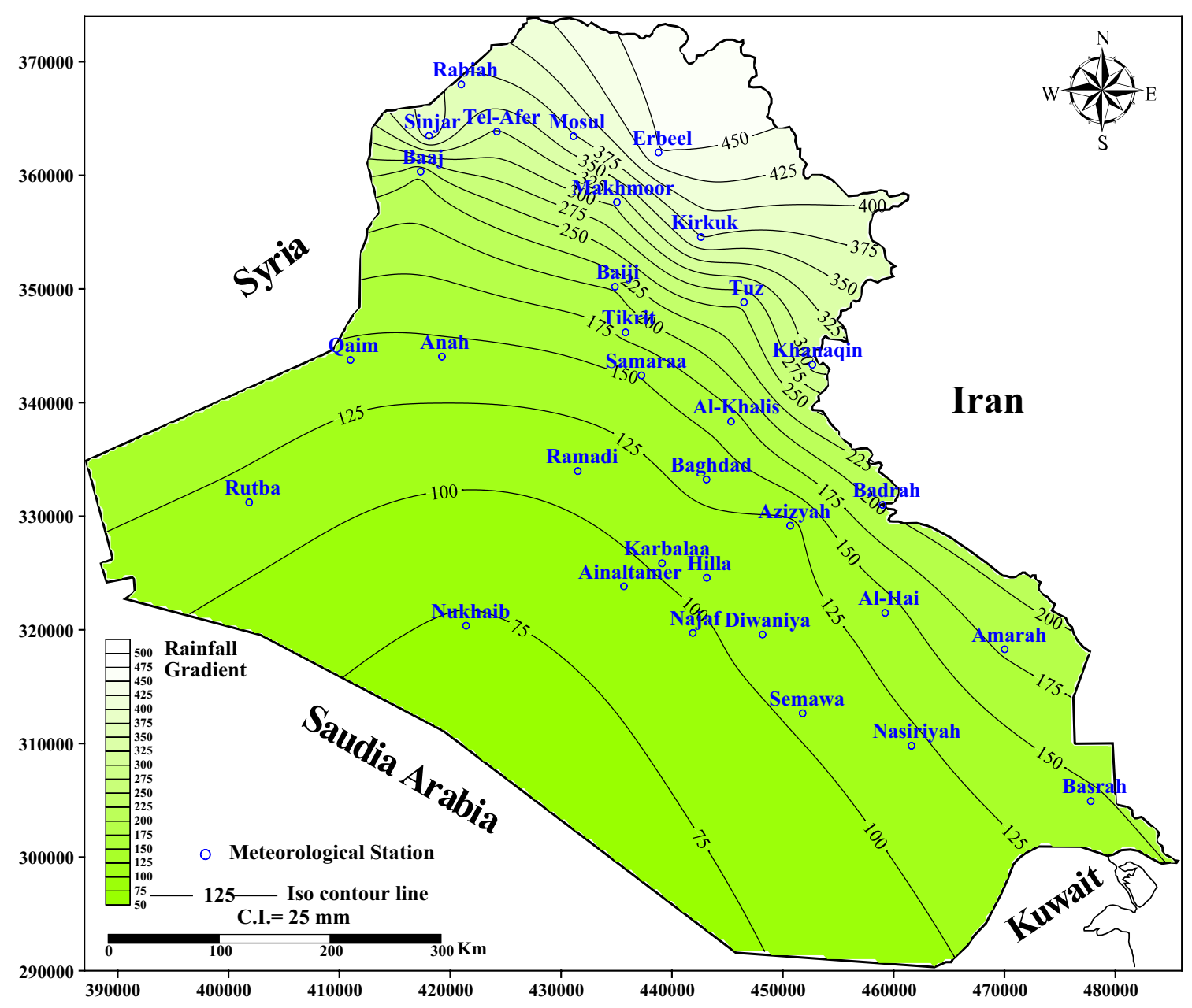

Fig. 2 Contour map of annual summation of rainfall in Iraq

\section{Methodology}

Temperature as a key factor controlling on potential evapotranspiration (PE) can be obtained by using data recorded in meteorological stations. Thirty-two stations were used all over Iraq, where annual and monthly air temperatures were adopted to calculate potential evapotranspiration (PE) using Thornthwaite method. The results of corrected potential evapotranspiration ( $\mathrm{PEc}$ ) were compared with annual and monthly rainfall in each station to obtain actual evapotranspiration (AE) using water balance equation. Water surplus was divided into runoff and natural groundwater recharge where runoff coefficient method was used to estimate runoff depending on Eq. (1) mentioned above which can be rewritten as follows:

$$
\begin{aligned}
& \text { Rainfall }(P)-[\text { evaporation }(E)+\operatorname{transpiration}(T) \\
& \quad+\text { evapotranspiration }(\mathrm{ET})+\operatorname{soil} \text { moisture }(\mathrm{So}) \\
& \quad+\operatorname{runoff}(\operatorname{Rof})+\operatorname{groun} d w a t e r \text { recharge }(\mathrm{GWR})] \\
& \quad=\text { change in storage }(\Delta S) .
\end{aligned}
$$

Finally, excel and Surfer programs presented results and demonstrate contour map of rainfall, water surplus (WS), runoff, and natural groundwater recharge in Iraq.

\section{Results and discussion}

Using Thornthwaite formula (Thornthwaite 1948) given in Eqs. (2-5) previously, the monthly corrected potential evapotranspiration $(\mathrm{PEc})$ was calculated after using correction factor of sunlight duration and number of day light according to latitude. Table 2 shows the mean annual rainfall, (PEc), (AE), and water surplus (WS) in each meteorological station in Iraq. Depending on Table 2, the mean annual summation of rainfall in (32) stations is demonstrated in Fig. 2, while Fig. 3 shows the distribution of actual evapotranspiration (AE) in Iraq.

It seems that mean annual summation of rainfall has a symmetrical increasing pattern from southwest toward northeast according to increasing ratio of rainfall due to 


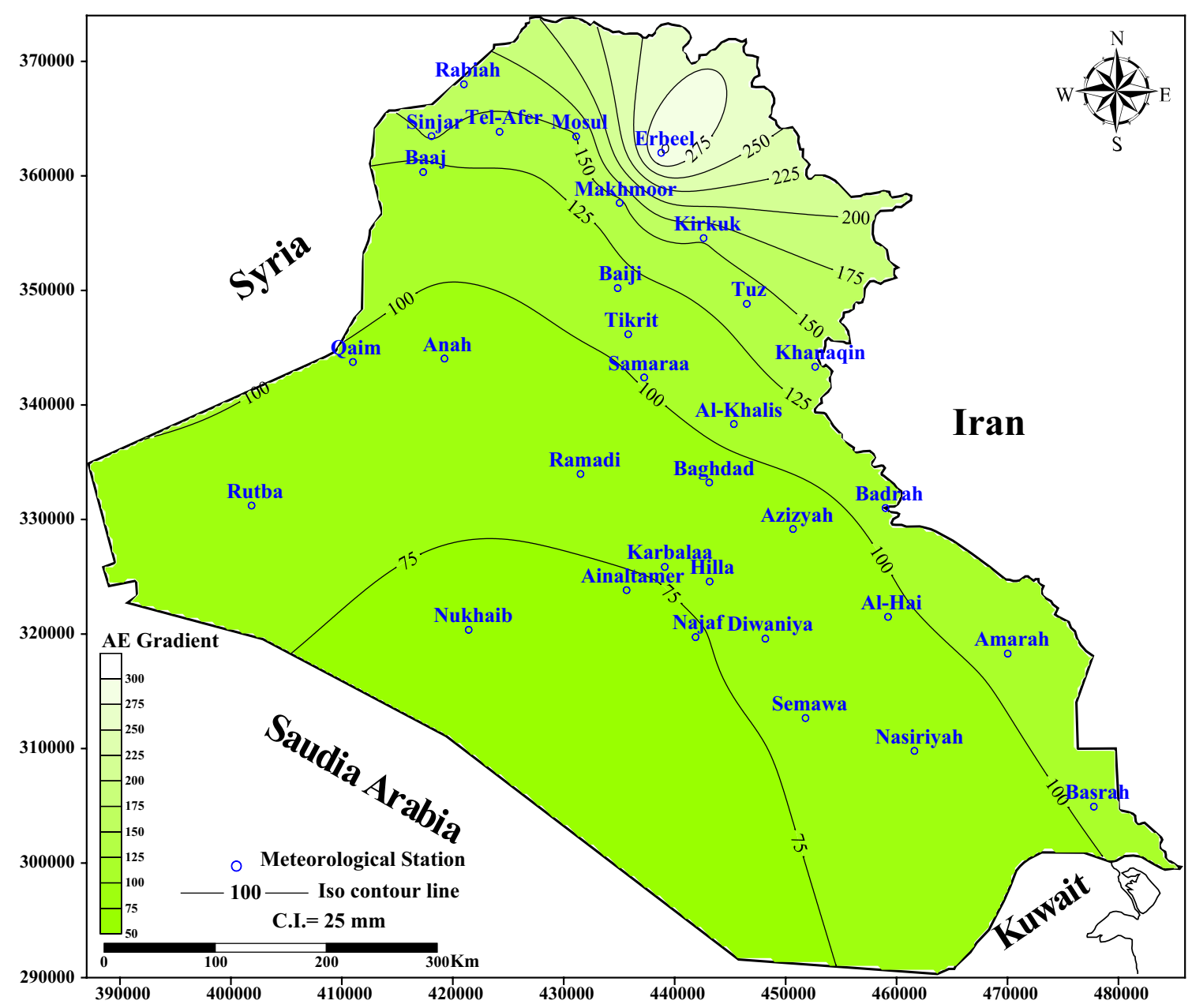

Fig. 3 Contour map of actual evapotranspiration (AE) in Iraq

impact of Mediterranean climate condition on Iraq. On the other hand, the distribution of actual evapotranspiration (AE) as shown in Fig. 3 has a similar pattern of rainfall distribution. Since actual evapotranspiration depends directly on water excess during calculating water balance, and whenever potential evapotranspiration was less than rainfall, the actual evapotranspiration will be equal to potential evapotranspiration which will produce water surplus. Whenever potential evapotranspiration was greater than rainfall, the actual evapotranspiration will be equal rainfall producing water deficit (Subedi and Chávez 2015; Al-Sudani 2018b, 2019a, d).

Figure 4 shows the obtained water surplus contour map in Iraq depending on water balance equation. The map shows the same pattern of rainfall distribution and actual evapotranspiration regarding increased values toward northeast direction of Iraq. The water surplus depends directly on both rainfall and actual evapotranspiration.

A mathematical relationship between mean annual of rainfall with both annual summation of water surplus and annual summation of actual evapotranspiration was obtained as shown in Fig. 5. The coefficient of determination were (99.2\%) and (95.37\%) for the first and second relationship, respectively. These two relationships can be used to obtain water surplus or actual evapotranspiration directly from mean annual rainfall as they are the major outputs of water balance equation.

Runoff coefficient method (Garg 2013) was used to calculate runoff by applying following formula:

$Q=K P$, 


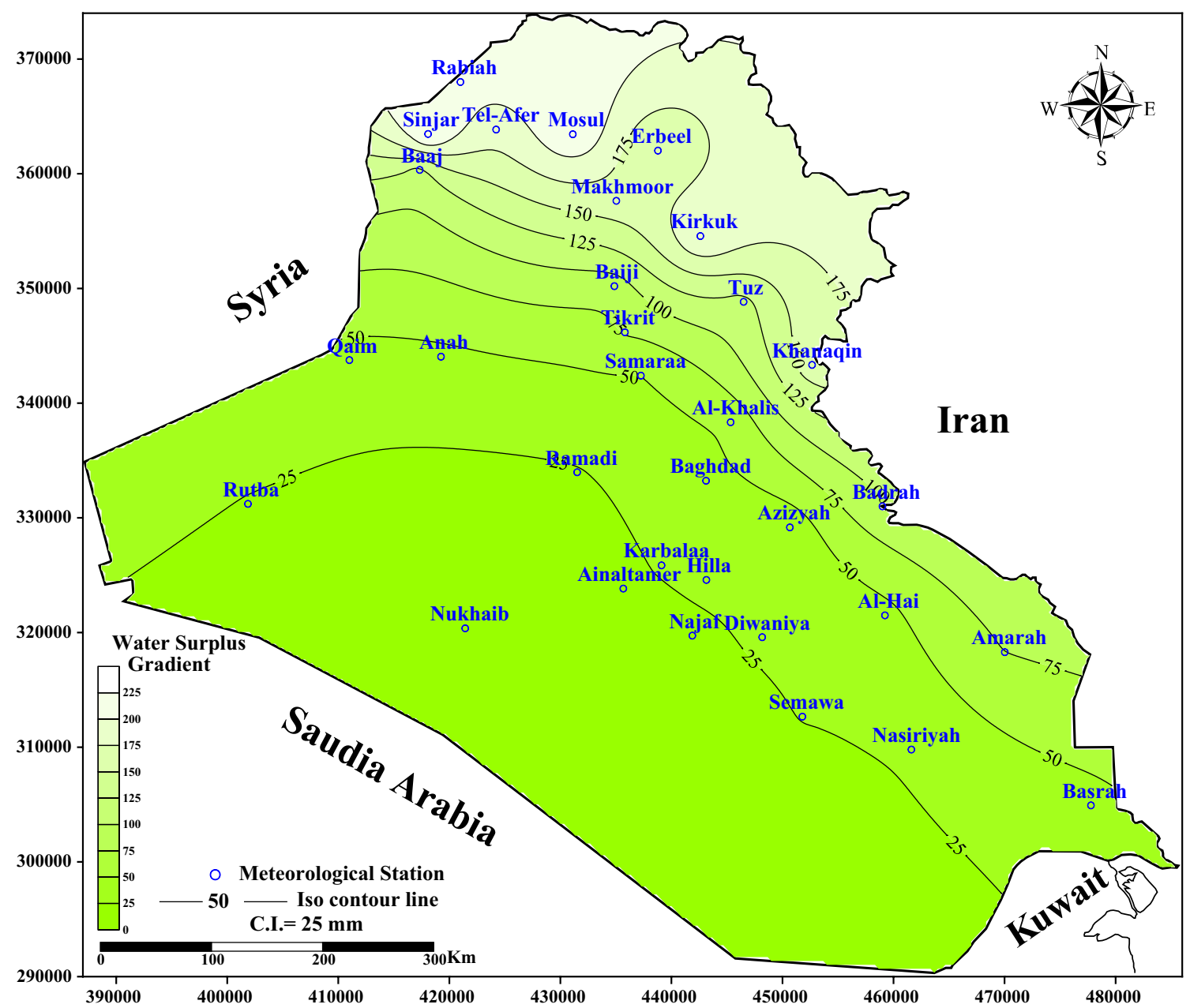

Fig. 4 Contour map of annual water surplus (WS) in Iraq

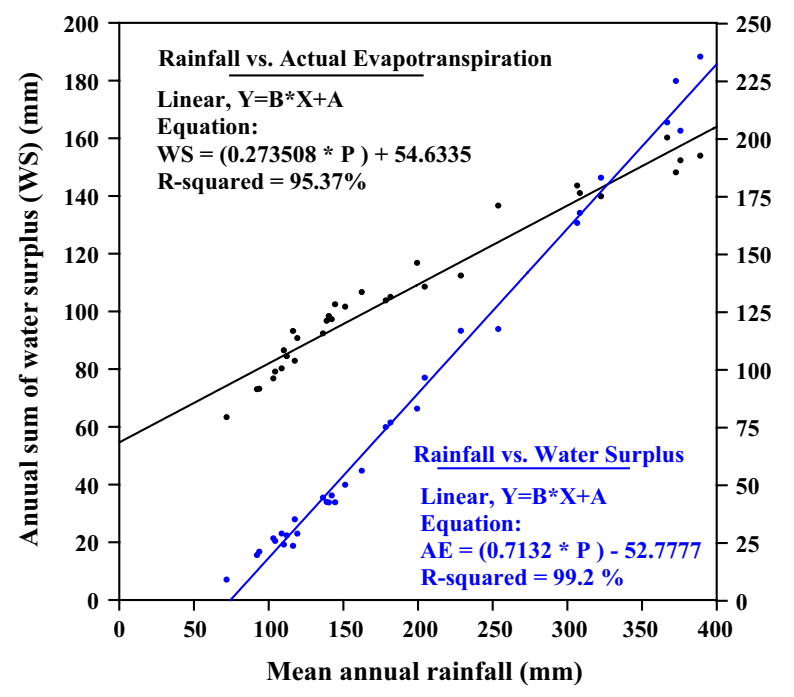

Fig. 5 The relationship of rainfall versus (WS) and (AE) where $Q$ runoff $P$ precipitation and $K$ a constant having a value less than (1) or at most equal to (1).

The value of $K$ depends upon the imperviousness of the drainage area. Its value increases with the increase in imperviousness of the catchments area and may approach unity (1.0) as the area becomes fully impervious. The value of $K$ depended on roof type and was estimated as (0.1) depending on Muhaimeed et al. (2014). Table 3 shows water balance components as actual evapotranspiration (AE), water surplus (WS), runoff, and groundwater recharge. Figure 6 shows contour map of annual runoff, while Fig. 7 shows contour map of annual groundwater recharge in Iraq.

As shown in both Figs. 6 and 7 the minimum values of runoff and groundwater recharge located in southwest direction of Iraq (western desert). These values were calculated depending on water balance and water surplus which indicate that climate conditions of desert area. These conditions 
Table 3 Water balance component as (AE) and (WS), runoff, and groundwater recharge

\begin{tabular}{|c|c|c|c|c|c|}
\hline St. no. & $\begin{array}{l}\text { Ave. sum of } \\
\text { rainfall }(\mathrm{mm})\end{array}$ & $\begin{array}{l}\text { Ave. sum of actual } \\
\text { evapotranspiration } \\
(\mathrm{mm})\end{array}$ & $\begin{array}{l}\text { Ave. sum of } \\
\text { water surplus } \\
(\mathrm{mm})\end{array}$ & $\begin{array}{l}\text { Ave. sum of } \\
\text { runoff }(\mathrm{mm})\end{array}$ & $\begin{array}{l}\text { Ave. sum of ground- } \\
\text { water recharge }(\mathrm{mm})\end{array}$ \\
\hline 1 & 92.469 & 72.88234 & 19.58666 & 9.2469 & 10.33976 \\
\hline 2 & 178.687 & 103.6623 & 75.02467 & 17.8687 & 57.15597 \\
\hline 3 & 142.529 & 97.11806 & 45.41094 & 14.2529 & 31.15804 \\
\hline 4 & 117.814 & 82.7288 & 35.0852 & 11.7814 & 23.3038 \\
\hline 5 & 229.04 & 112.2714 & 116.7686 & 22.904 & 93.8646 \\
\hline 6 & 204.843 & 108.4218 & 96.42122 & 20.4843 & 75.93692 \\
\hline 7 & 136.702 & 92.2237 & 44.4783 & 13.6702 & 30.8081 \\
\hline 8 & 199.6981 & 116.6699 & 83.02824 & 19.96981 & 63.05843 \\
\hline 9 & 144.805 & 102.3255 & 42.47953 & 14.4805 & 27.99903 \\
\hline 10 & 112.441 & 84.34017 & 28.10083 & 11.2441 & 16.85673 \\
\hline 11 & 139.17 & 96.59776 & 42.57224 & 13.917 & 28.65524 \\
\hline 12 & 108.981 & 80.0853 & 28.8957 & 10.8981 & 17.9976 \\
\hline 13 & 103.4592 & 76.60349 & 26.85571 & 10.34592 & 16.50979 \\
\hline 14 & 162.6836 & 106.5557 & 56.12789 & 16.26836 & 39.85953 \\
\hline 15 & 308.659 & 140.8596 & 167.7994 & 30.8659 & 136.9335 \\
\hline 16 & 376 & 152.2042 & 223.8048 & 37.6 & 165.7935 \\
\hline 17 & 306.914 & 143.459 & 163.455 & 30.6914 & 132.7636 \\
\hline 18 & 372.995 & 148.0522 & 224.9428 & 37.2995 & 187.6433 \\
\hline 19 & 94.05 & 73.0197 & 21.0303 & 9.405 & 11.6253 \\
\hline 20 & 72.1554 & 63.18704 & 8.96836 & 7.21554 & 1.75282 \\
\hline 21 & 119.4807 & 90.5997 & 28.881 & 11.94807 & 16.93293 \\
\hline 22 & 140.624 & 98.24673 & 42.37727 & 14.0624 & 28.31487 \\
\hline 23 & 367.12 & 160.1051 & 207.0149 & 36.712 & 170.3029 \\
\hline 24 & 110.512 & 86.3939 & 24.1181 & 11.0512 & 13.0669 \\
\hline 25 & 116.65 & 93.06902 & 23.58918 & 11.665 & 11.92418 \\
\hline 26 & 151.5433 & 101.488 & 50.05526 & 15.15433 & 34.90093 \\
\hline 27 & 104.682 & 78.98249 & 25.69951 & 10.4682 & 15.23131 \\
\hline 28 & 389.308 & 153.8117 & 235.4963 & 38.9308 & 196.5655 \\
\hline 29 & 322.8445 & 139.7751 & 183.0694 & 32.28445 & 150.7849 \\
\hline 30 & 181.878 & 104.8913 & 76.9867 & 18.1878 & 58.7989 \\
\hline 31 & 254.026 & 136.522 & 117.504 & 25.4026 & 92.1014 \\
\hline 32 & 449 & 305.302 & 143.697 & 44.9 & 98.79771 \\
\hline
\end{tabular}

was the major influence on rising temperature resulting increased values of potential evapotranspiration which effect directly on actual evapotranspiration. The opposite influence of these conditions leads to reducing rainfall which is the only input component of water balance.

\section{Conclusions}

1. Actual evapotranspiration depends directly on water excess during calculating water balance.
2. Water surplus contour map indicates increased values toward northeast direction of Iraq, where water surplus depends directly on both rainfall and actual evapotranspiration.

3. The minimum values of runoff and groundwater recharge located in western desert of Iraq.

4. The obtained mathematical relationship between rainfall with both water surplus and actual evapotranspiration can be used to estimate these two parameters directly from rainfall. 


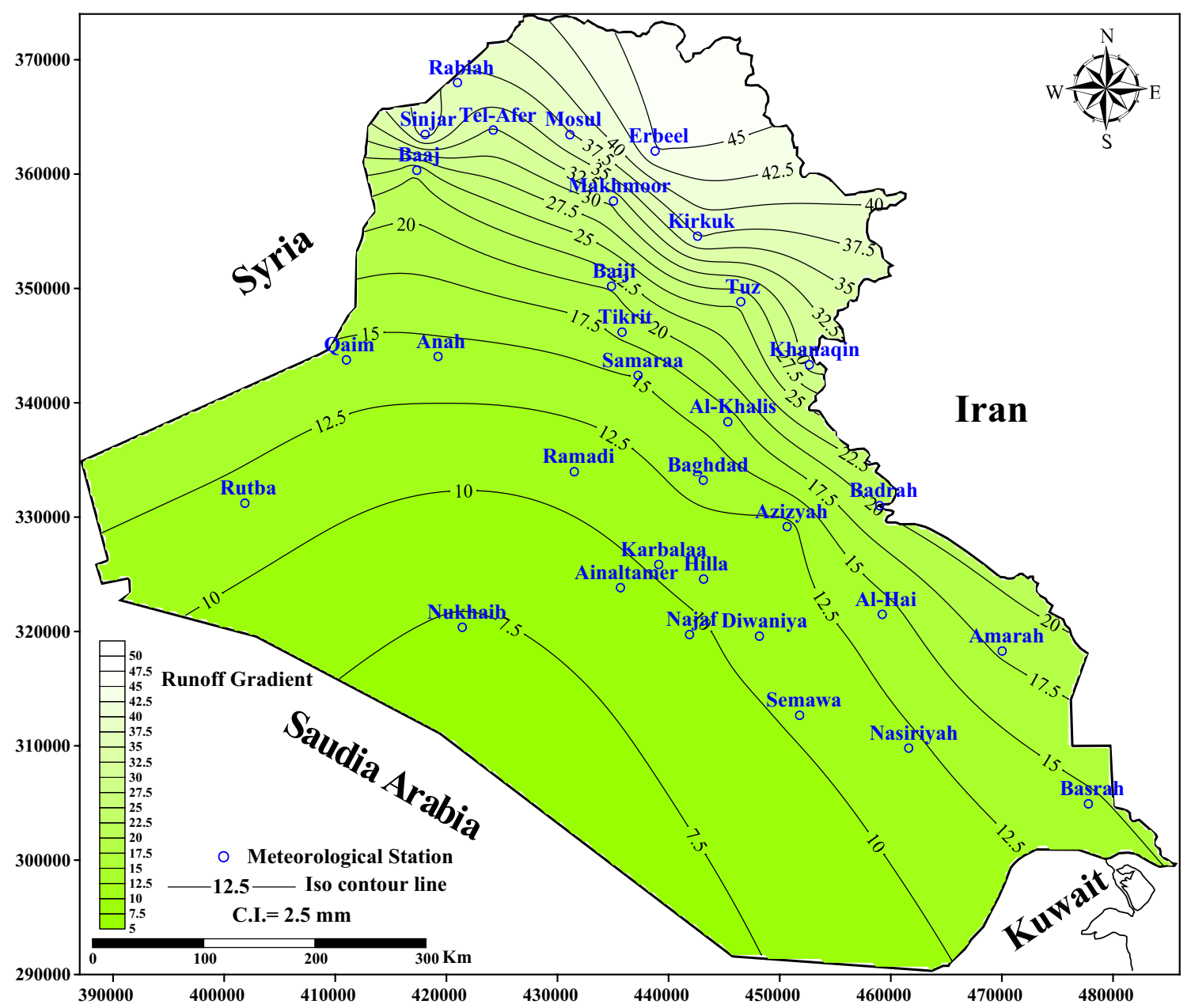

Fig. 6 Contour map of annual runoff in Iraq

5. The climate conditions of desert were the major influence on reducing rainfall and rising temperature resulting decreasing water surplus, runoff, and groundwater recharge.

6. Iraq can be divided into five distinguished hydrological zones, where topographical, geological, and climatic characteristics of these zones produced distinguished hydrological and hydrogeological conditions (Al-Sudani 2019f). Depending on these zones characteristics, future local studies in each zone will be done depending on results of this research as well as all data collected related to geological, hydrological, and hydogeological investigation and local climate condition in order to optimize the results of water surplus and natural groundwater recharge. 


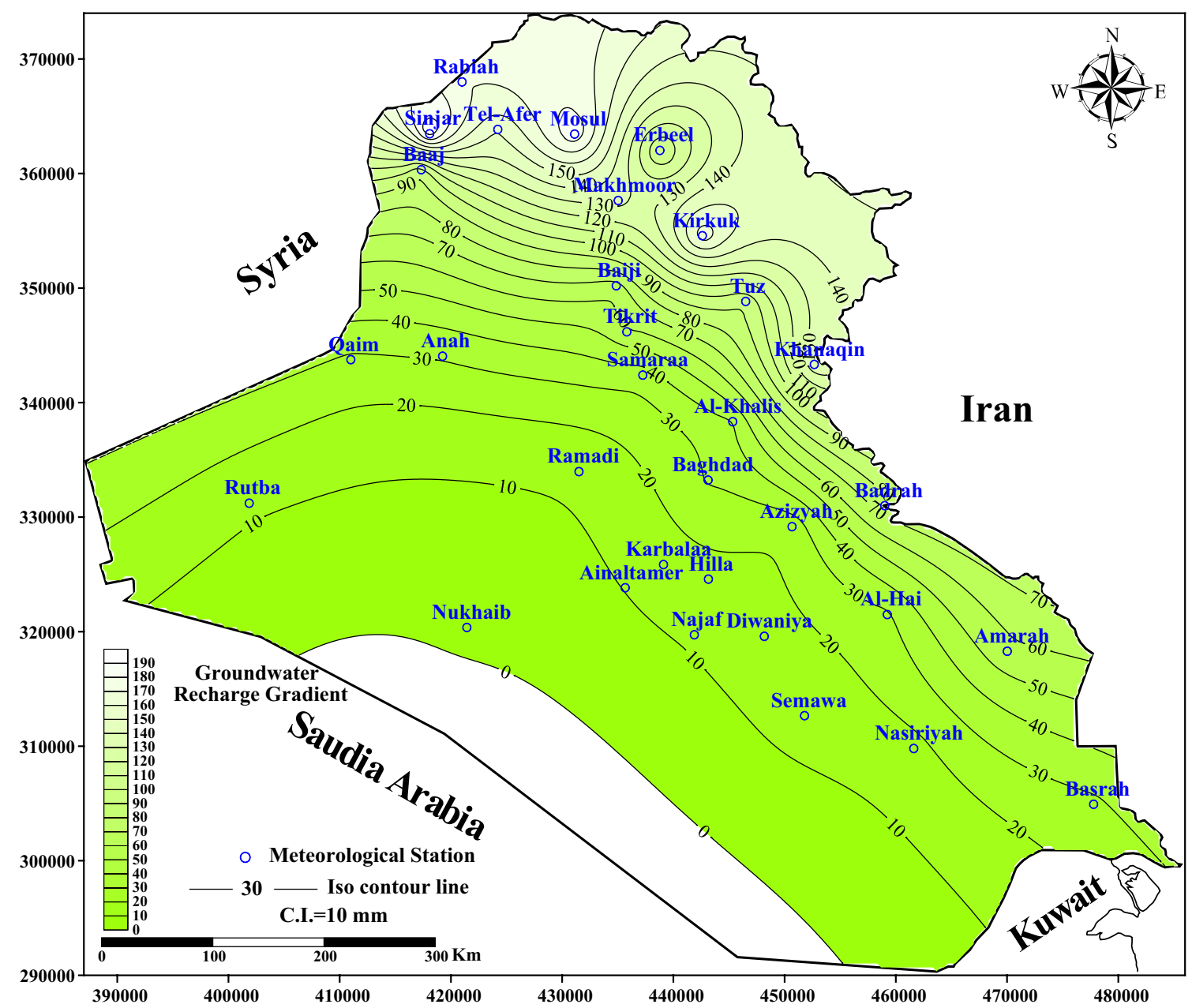

Fig. 7 Contour map of annual groundwater recharge in Iraq

\section{Compliance with ethical standards}

Conflict of interest The author declares that he have no conflict of interest.

Open Access This article is licensed under a Creative Commons Attribution 4.0 International License, which permits use, sharing, adaptation, distribution and reproduction in any medium or format, as long as you give appropriate credit to the original author(s) and the source, provide a link to the Creative Commons licence, and indicate if changes were made. The images or other third party material in this article are included in the article's Creative Commons licence, unless indicated otherwise in a credit line to the material. If material is not included in the article's Creative Commons licence and your intended use is not permitted by statutory regulation or exceeds the permitted use, you will need to obtain permission directly from the copyright holder. To view a copy of this licence, visit http://creativecommons.org/licenses/by/4.0/.

\section{References}

Abdullah SS, Malek M, Mustapha A, Aryanfar A (2014) Hybrid of artificial neural network-genetic algorithm for prediction of reference evapotranspiration (ET) in arid and semiarid regions. J Agric Sci 6(3): 191

Al-Kubaisi QY, Rasheed AA (2018) Climatic water balance and hydrogeological characteristics of Lailan Basin, Southeast KirkukNorth of Iraq. Iraqi J Sci 59(1A):105-118

Allen RG, Pereira LS, Raes D, Smith M (1998) Crop evapotranspiration-guidelines for computing crop water requirements-FAO irrigation and drainage paper 56. FAO, Rome

Al-Shamma A, Taqa ES, Saeed MAH (2007) Water balance of North Erbil Basin. Iraqi J Sci 48(1):124-134

Al-Sudani HI (2003) Hyrogeological system of Debagah basin in North of Iraq. PhD thesis, University of Baghdad, College of Science, p 153

Al-Sudani HIZ (2018a) Calculating of groundwater recharge using meteorological water balance and water level fluctuation in Khan Al-Baghdadi Area. Iraqi J Sci 59(1B):349-359

Al-Sudani HIZ (2018b) Study of morphometric properties and water balance using Thornthwaite method in Khanaqin Basin, East of Iraq. J Univ Babylon Eng Sci 26(3):165-175

Al-Sudani HIZ (2019a) Temperature-potential evapotranspiration relationship in Iraq using Thornthwaite method. J Univ Babylon Eng Sci 27(1):16-25

Al-Sudani HIZ (2019b) Derivation mathematical equations for future calculation of potential evapotranspiration in Iraq, a review of 
application of Thornthwaite evapotranspiration. Iraqi J Sci 60(5):1037-1048

Al-Sudani HIZ (2019c) Groundwater system of Dibdibba sandstone aquifer in south of Iraq. Appl Water Sci 9(4):1-11

Al-Sudani HIZ (2019d) Estimation of water balance in Iraq using meteorological data. Int J Recent Eng Sci 6(5):8-13

Al-Sudani HIZ (2019e) Rainfall returns periods in Iraq. J Univ Babylon Eng Sci 27(2):1-9

Al-Sudani HIZ (2019f) Groundwater zones in Iraq. No 4. https://www. researchgate.net/publication/336497608

Al-Sudani HIZ, Jawad SB, Jawad MA (2000) Hydrogeological investigations for sector 9.5th stage, Badra-Jassan Region, East of Iraq. Report no 1. https://www.researchgate.net/publication/319665617

Domemico PA, Schwartz FW (1998) Physical and chemical hydrogeology. Wiely, New York, p 506

Garg SK (2013) Irrigation engineering and hydraulic structures, 27th edn. Khanna Publishers, New Delhi

Henderson A (2012) The future of the world's climate, 2nd edition. Henderson-Sellers A, McGuffie K (eds). Elsevier, Boston, pp 531-621

Iraqi Meteorological Organization and Seismology (2015) Meteorological data of (32) meteorological station for different periods. Internal report. Ministry of Transportation, Baghdad

Jawad SB, Ridha SA (2008) Assessment of groundwater resources in Iraq and management of their use. General Commission of Water Resources Management. Ministry of Water Resources, Baghdad, $19 \mathrm{p}$
Mohammed R, Scholz M (2017) Impact of evapotranspiration formulations at various elevations on the reconnaissance drought index. Water Resour Manag 31:531-548. https://doi.org/10.1007/s1126 9-016-1546-9

Muhaimeed AS, Saloom AJ, Saliem KA, Alani KA, Muklef WM (2014) Classification and distribution of Iraqi soils. Int J Agric Innov Res 2(6):997-1002

Saud A, Azlin Md, Said Md, Abdullah R, Hatem A (2016) Investigation of water balance methods of Haqlan Basin in the western region of Iraq. World Appl Sci J 34(5):652-656

Sokolov AA, Chapman TG (1974) Methods for water balance computations, an international guide for research and practice. UNESCO Press, Paris, p 127p

Subedi A, Chávez JL (2015) Crop evapotranspiration (ET) estimation models: a review and discussion of the applicability and limitations of ET methods. J Agric Sci 7(6):50

Thornthwaite CW (1948) An approach toward a relation classification of climate. Geograph Rev 32(55):3-30

UNESCO (1971) Scientific framework of world water balance. Technical papers in hydrology, no. 7, Paris, $27 \mathrm{p}$

Vangelis H, Tigkas D, Tsakiris G (2013) The effect of PET method on reconnaissance drought index (RDI) calculation. J Arid Environ $88: 130-140$

Publisher's Note Springer Nature remains neutral with regard to jurisdictional claims in published maps and institutional affiliations. 